\title{
The Relationship Between CEO Gender, Financial Performance, And Financial Management
}

Terrance Jalbert, Ph.D., University of Hawaii at Hilo, USA

Mercedes Jalbert, The Institute for Business and Finance Research, USA

Kimberly Furumo, Ph.D., University of Hawaii at Hilo, USA

\begin{abstract}
In recent years, the number of female Chief Executive Officers (CEO's) at large firm's has increased to the point that it is possible to statistically compare the performance and management characteristics of firms managed by CEO's of different genders. This paper is an exploratory study that examines the relationship between CEO gender and the performance and management of publicly traded firms. We use a large dataset of annual Forbes CEO data, combined with Compustat data, covering the time period of 1997 to 2006. Our results show that CEO gender is related to a number of factors including inside ownership and return on assets.
\end{abstract}

Keywords: Gender; CEO; Chief Executive Officer; Firm Performance; Financial Management

\section{INTRODUCTION}

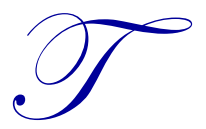

hroughout history, males have predominantly occupied the largest United States firm's CEO (Chief Executive Officer) positions. More recently, females have breached this glass ceiling and increasingly take on CEO responsibilities. This opens the door to examine questions about how gender affects CEO management style, firm performance and how much investors will pay to purchase the firm. Sufficient data is now available to conduct meaningful statistical analysis to answer these questions. Nevertheless, little academic research exists on the performance of CEO's in the largest United States firms as it relates to CEO gender.

This exploratory study examines the extent that CEO gender explains firm management and market performance indicators. We use data from the annual Forbes Compensation List supplemented with data from Standard and Poor's Compustat. The data covers the time period 1997-2006. The results show that CEO gender explains several important firm management variables. Female CEO's either operate their firms differently, or alternatively are hired to manage firms having certain characteristics. The remainder of the paper is organized as follows. In the next section, we examine the relevant literature. Next, we discuss the data and methodology used in the paper. The results of statistical tests follow. The paper closes with some concluding comments.

\section{LITERATURE REVIEW}

Wiersema and Bantel (1992) found that CEO demographics affect firm performance. They show that time in position, years with the firm, educational level, and functional background impact firm performance. Barker and Mueller (2002) examined how CEO background relates to R\&D spending. They found, significant R\&D spending increases at firms where the CEO earned an advanced science degree. Gabaix and Landier (2008) found small differences in CEO talent justify large pay differences. Their findings indicate that increases in CEO pay from 1980 through 2003 can be fully attributed to increases in market capitalization of large companies. Hermalin (2005) argues that improved corporate governance explains CEO compensation increases. Higher pay compensates for the increased chance of being fired. 
Jalbert, Rao, and Jalbert (2002) identify preferred educational backgrounds for selection as CEO of a major corporation. They find that CEOs without a college degree earn significantly more than those with a college degree. They find little evidence that the school attended affects CEO compensation. Jalbert, Jalbert and Perrina (2004), examined the specific degrees earned by CEOs as it relates to the salary earned as CEO. The results indicate the total compensation individuals earn as CEO depends upon the degrees the individual holds. They found those with different degrees were with the firm for differing numbers of years, started working for the firm and became CEO at different ages, and were with the firm for varying amounts of time prior to becoming CEO.

Gottesman and Morey (2006) find firms with CEOs from more prestigious schools do not outperform other CEOs. Firms managed by CEOs with MBA or law degrees do not outperform firms with CEOs without a graduate degree. However, their results indicate that compensation is somewhat higher for CEOs who attend more prestigious schools. Palia (2000) examined how a CEO's educational background impacts the type of firms they manage. He compared the performance of individuals based on the prestige of the university where they earned their undergraduate and graduate degrees. The results indicate managers with lower quality educational backgrounds manage firms in regulated industries and those with higher quality educational backgrounds manage firms in unregulated industries.

Palia and Ravid (2002) found that founders are less responsive to performance incentives and that founder run firms are more profitable. However, they found that firms led by family members of the original founders have lower market values. Fahlenbrach (2009) found that firms managed by a founder invest more in R\&D, have higher capital expenditures and made more focused mergers and acquisitions. He also found that investing in founder managed firms produced a 4.4\% annual abnormal return. Jalbert and Jalbert (2005) found that founders earn higher compensation than their non-founder counterparts. Moreover the authors found significant differences between founders and non-founders in the ages when CEOs earned their degrees, age at which they started working for the company and age at which they become CEO. Founders tend to finish their degrees prior to entering the work force, while non-founders tend to enter the workforce prior to earning their degree.

\section{DATA AND METHODOLOGY}

Since 1973, Forbes magazine has published an annual list containing information about the CEO's of large United States companies. The Forbes list includes information about compensation and other variables for up to 800 CEOs each year. Forbes reduced the number of firms included in the analysis from 800 to 500 in 2002 . Forbes selects firms for inclusion in the list based on firm size. This study is based on the Forbes Compensation List. Forbes provided the authors with some data in electronic format. Others were obtained from lists presented on the Forbes website. The Data covers a ten year period 1997-2006 including 6,305 annual firm observations. Each firm in the Forbes list was matched with its corresponding ticker symbol. Next, supplemental financial data on each firm were obtained from Standard and Poor's Compustat.

The primary variable of interest in the study was the CEO gender. Each CEO name in the database was analyzed to determine if the CEO was male or female. The variable GENDER equals one if the CEO is female and zero if the CEO is male. For those observations where the gender was not obvious based on the individual's name, an internet search was conducted to identify gender. The data includes 77 observations with a Female CEO and 6,228 observations with a male CEO. Thus, females account for 1.22 percent of the total CEO population. Jalbert, Furumo and Jalbert (2011) find that female CEO's earn higher compensation than male CEO's. However, they find no evidence to suggest that firms managed by female CEO's outperform other firms.

Of further interest is the extent to which attending an Association to Advance Collegiate Schools of Business AACSB accredited school impacts the dependent variables. To examine this issue, we identify observations where the CEO earned either an undergraduate or a graduate degree from an AACSB accredited school. Accreditation information from the AACSB website permitted us to make this determination. The dummy variable, $A A C S B$, equals one if the individual earned a degree from an AACSB accredited school and zero otherwise. The data includes 5,272 observations where the CEO earned either a graduate degree or an undergraduate degree from an AACSB accredited school and 1,033 observations where neither an undergraduate or 
graduate degree was earned from an AACSB accredited school. Jalbert, Jalbert and Furumo (2011) find that firms with CEO's from AACSB accredited schools tend to underperform those with CEO's from other schools.

We include four additional demographic variables related to the CEO. We include a dummy variable indicating if the CEO is the founder of the company. The variable Founder equals 1 if the current CEO is the firm founder. The variable equals zero if the current CEO is not the founder of the company. We do not control for the effects of a founding CEO that leaves the company, then returns at a later time. Years with the company indicates the number of years the individual has worked for the firm. Years as CEO, indicates the number of years the individual has served as the firm's CEO. Total Compensation is the total remuneration the CEO receives for his or her services to the firm. Total compensation, $T C$, as reported by Forbes magazine, measures the reward the CEO receives for all activities performed by the firm. This variable includes salary, bonus, stock compensation and other compensation. Murphy (2003) and Murphy and Hall (2002) document the importance of differentiating between compensation components. However, this analysis is limited to a single measure of compensation.

To identify differences in performance by CEO's, we examine Return on Assets, Return on Equity and Return on Investment. These variables indicate how effectively the CEO utilizes the assets, equity and investments in the firm. To control for the well-known size effect we include the total assets of the firm. Related to total assets is the sales growth of the firm. Sales growth measures how fast sales are increasing thereby providing the opportunity to increase the asset base and profits. We also incorporate Free Cash Flows in the model to reflect the ability of the firm to finance profitable projects.

CEOs have exclusive or significant control over capital structure and dividend policy which indicate how the firm's assets are financed. Readers interested in the capital structure decision are referred to Modigliani and Miller (1958); Modigliani and Miller (1963); Miller (1977); DeAngelo and Masulis (1980); and Jalbert (2002). Miller and Modigliani (1961) argued that in an idealized world, dividends do not affect firm value. However, other authors find that dividends have important roles within the firm (Easterbrook, 1984; and Bhattacharyya, Mawani and Morrill, 2008a and 2008b). The dividend payout ratio of the firm, PAYOUT, and debt to assets ratio, Debt-toAssets, are incorporated into the analysis to capture managerial effects.

Three variables measure the shareholder perceptions. Institutional ownership and Inside Ownership measure the willingness of certain groups to purchase the firm's stock. Insider and Institutional owners commonly have better information than other investors. Higher levels of ownership by these individuals indicate they have a positive perception of the firm's prospects. Price to book measures the amount that investors are willing to pay for the net assets of the firm. Higher price to book ratios indicate that stockholders are willing to pay more for one dollar of net assets.

It is well established that firms in different industries are operated and valued differently. To control for these effects we include an industry indicator variable, Global Industry Classification Standard, GICS. We also include a variable year. The year variable indicates the year for which the observation relates, ranging from 19972006. The year variable controls for changing relationships between the independent and dependent variables across time.

Some descriptive statistics of seventeen variables included in the analysis are presented in Table 1. As show in Table 1, the variables occur in the dataset with differing frequency. Inside ownership information is included for 4,619 observations. Data on CEO Gender and if the CEO founded the firm is available for all 6305 observations in the dataset. 
Table 1: Descriptive Statistics

\begin{tabular}{|l|c|c|c|c|c|}
\hline \multicolumn{1}{|c|}{ Variable } & Observations & Mean & Max & Min & $\begin{array}{c}\text { Standard } \\
\text { Deviation }\end{array}$ \\
\hline ROE & 5,576 & 13.02 & 5,625 & $-6,164$ & 153.30 \\
\hline ROA & 5,739 & 4.10 & 132.78 & -492.11 & 14.47 \\
\hline ROI & 5,678 & 8.38 & 905.71 & $-1,173$ & 34.73 \\
\hline Gender & 6,305 & 0.01221 & 1 & 0.00 & 0.1098 \\
\hline Total Assets & 5,740 & 32,669 & $1,884,318$ & 0.1810 & 104,760 \\
\hline Inside Ownership & 4,619 & 11.04 & 189.13 & 0.00 & 2.16 \\
\hline Institutional Ownership & 4,658 & 75.099 & 140.62 & 0.00 & 140.62 \\
\hline Payout & 5,699 & 27.08 & 30,516 & $-34,928$ & 681.69 \\
\hline Free Cash Flow & 4,942 & 374.89 & 77,094 & $-50,115$ & 3,099 \\
\hline Debt to Assets & 5,723 & 26.19 & 691.58 & 0 & 22.61 \\
\hline Sales Growth & 5,730 & 33.83 & 54,280 & -100 & 726.15 \\
\hline Total Compensation & 6,200 & 8,225 & 706,077 & 0.00 & 24,047 \\
\hline Price to Book & 4,895 & 6.239 & 5332 & $-1,638$ & 99.571 \\
\hline Price to Earnings & 5,085 & 38.10 & 6,344 & 0.2220 & 177.36 \\
\hline Founder & 6,305 & 0.090 & 1 & 0.00 & 0.2863 \\
\hline Years with Company & 6,237 & 19.672 & 66 & 0.00 & .050 \\
\hline Years as CEO & 6,051 & 7.816 & 60 & & 12.375 \\
\hline
\end{tabular}

This table shows descriptive statistics of the variables used in the analysis.

\section{RESULTS} model:

The empirical analysis begins by completing a series of single regressions. Equation 1 shows the estimated

Dependent Variable $=\alpha+\beta($ Gender $)+\varepsilon$.

As noted earlier, Gender is a dummy variable that equals 1 for a female CEO and zero for a male CEO. Table 2 shows the results of this regression incorporating several dependent variables. The results show that CEO gender has significant explanatory power for four variables. CEO gender explains Return on Investment, ROI, but does not explain Return on Assets, $R O A$, or Return on Equity, ROE. Gender explains the Price to Earnings Ratio, $P E$, but it does not explain the Price to Book ratio, $P B$. The positive coefficient on the $P E$ variable indicates that investors are willing to pay more to acquire firms that are managed by a female. Gender explains the Debt Ratio as well as the industry. The results suggest that women serve as CEOs in some industries more often than others. Moreover, female CEO's finance their firms differently than male CEO's. In each regression the R2 statistic is low. The highest R2 occurs for the $P E$ ratio at 0.0065 .

Table 2: Regressions on Gender

\begin{tabular}{|l|c|c|c|c|c|c|}
\hline \multicolumn{1}{|c|}{ Dependent Variable } & $\begin{array}{c}\text { Independent } \\
\text { Variable }\end{array}$ & Observations & Intercept & Coefficient & T-Statistic & R2 \\
\hline ROA & Gender & 5,739 & 4.110 & -0.8036 & -0.480 & 0.0000 \\
\hline ROI & Gender & 5,678 & & & $-2.23^{* *}$ & 0.0009 \\
\hline ROE & Gender & 5,576 & 13.079 & -5.358 & -0.280 & 0.0000 \\
\hline Price to Earnings & Gender & 5,085 & 36.465 & 126.230 & $5.760 * * *$ & 0.0065 \\
\hline Sales Growth & Gender & 5,730 & 33.495 & 24.718 & 0.30 & 0.0000 \\
\hline Price to Book & Gender & 4,895 & 6.105 & 9.356 & 0.780 & 0.0001 \\
\hline Inside Ownership & Gender & 4,619 & 11.0223 & 1.4857 & 0.520 & 0.0001 \\
\hline Institutional Ownership & Gender & 4,658 & 75.090 & 0.78869 & 0.280 & 0.0000 \\
\hline Free Cash Flow & Gender & 4,924 & 375.50 & -45.343 & -0.120 & 0.0000 \\
\hline CEO Compensation & Gender & 6,200 & 8,253 & $-2,281$ & -0.820 & 0.0001 \\
\hline Debt to Assets & Gender & 5,723 & 26.046 & 10.864 & $4.190 * * *$ & 0.0031 \\
\hline Payout Ratio & Gender & 5,699 & 27.121 & -3.413 & -0.040 & 0.0000 \\
\hline Total Assets & Gender & 5,740 & 32,842 & $-12,953$ & -1.080 & 0.0002 \\
\hline GICS & Gender & 6,016 & 32.628 & 6.073 & $4.220^{* * *}$ & 0.0029 \\
\hline
\end{tabular}

This table shows the results of regressions on gender. The estimated equations is: Dependent Variable $=\alpha+\beta(G e n d e r)+\varepsilon$. Gender is a dummy variable that equals 1 for a female CEO and zero for a male CEO. 
The analysis continues by incorporating control variables into the analysis. We run multiple regressions as specified in Equation 2.

Dependent Variable $=\alpha+\beta_{1}$ Gender $+\beta_{t}$ Control Variable $_{t}+\varepsilon$

Control Variable $_{t}$ is a vector of control variables that may affect the impact of gender on the dependent variable. The other parameters in the model are as defined earlier. Table 3 shows the regression results for five dependent variables. The first column shows the regression results when $P E$ is the dependent variable. The results show that Gender significantly explains the Price to Earnings ratio, at the one percent level of significance, after considering the effects of sixteen control variables. The positive coefficient on Gender indicates that firms managed by females have higher price to earnings ratios. This implies that investors pay more for firms that are managed by females. Other significant variables include price to book ratio, Debt to Assets, Return on Assets, Payout, sales growth, years with the company and the observation year. The R2 and adjusted R2 for this regression equal 0.1066 and 0.1013 respectively. Variance inflation factors less than ten indicate multicollinearity is not an issue in a regression. The Variance Inflation Factor (VIF) for each variable in this regression is less than 1.76.

The second column shows the regression results for the dependent variable Return on Investment, ROI. Gender is significant in the regression at the one percent level. The positive coefficient on gender indicates that female CEO's produce more ROI, for their investors than male CEO's. Other significant variables include the price to book ratio, debt to assets, free cash flow, sales growth, inside ownership, institutional ownership, founder, total compensation, years as CEO and years with the company. Variance Inflation factors are each less than 1.70.

The third column shows the regression results when Return on Assets is the dependent variable. Again, gender is significant with a positive coefficient indicating that female CEOs produce higher return on assets. The control variables generally follow a similar pattern of significance as the ROI regressions. The exceptions are Industry, Total Assets, and year which are significant in the ROA regression, but not the ROI regression. Founder and years as $\mathrm{CEO}$ are significant in the $R O I$ regression but not in the $R O A$ regression. The regression produces an $\mathrm{R} 2$ of 0.1606 and an adjusted $\mathrm{R} 2$ of 0.1563 . The VIF is less than 1.70 for each variable.

The Sales Growth regression results presented in the fourth column of Table 3 shows a positive and significant Gender coefficient. The interpretation is that firms managed by females have higher Sales Growth than other firms. Other significant variables in this regression include price to book, debt to assets, ROA, Inside Ownership, Institutional Ownership, Founder, Total Compensation, Years as CEO, Years with the Company and Year. The regression has a R2 of 0.1337 and an adjusted R2 of 12.93. The VIF is less than 1.69 for each variable.

The final column in Table 3 shows the regression results for the dependent variable Institutional Ownership. Gender produces a negative and significant coefficient at the ten percent level. Industry is also significant indicating that different industries have differing levels of institutional ownership. Total assets, has a negative and significant coefficient indicating that smaller firms in the sample have more institutional ownership. Other significant variables include Free Cash Flow, ROA, Sales Growth, Inside Ownership, Years as CEO, Years with the company and AACSB accreditation. Interestingly, AACSB accreditation has a negative coefficient, indicating that institutional ownership is higher among firms with CEO's from universities that are not accredited. The R2 for this regression is 0.2211 and the adjusted R2 is 0.2171 . The VIF is less than 1.69 for each variable.

Next, we conduct stepwise regressions to determine which variables enter into the models significantly. Equation 2 above is estimated. Variables with a p-value less than 0.20 were allowed to enter into the model. To remain in the model the variable's p-value must be below 0.10 . The results are presented in Table 4 . The first figure in each cell is the parameter estimate. The second figure in each cell is the F-value. ***, ** and * indicate significance at the 1,5 and 10 percent levels respectively.

The results in Table 4 show that nine variables are significant in explaining the Price to Earnings ratio. Six variables are significant at the 1 percent level, two at the 5 percent level and one at the 10 percent level. Gender, with a coefficient of 163.52, is significant at the one percent level. The positive sign on Gender implies that investors pay a higher price to earnings ratio for firms managed by women. The positive coefficient on AACSB 
indicates that firms with managers from an AACSB accredited school have a higher price to earnings ratio than other firms. The R2 for the regression is 0.1052 .

The regressions on ROI indicate nine significant explanatory variables. Gender, along with three other variables is significant at the one percent level. Gender has a coefficient of 17.30. CEO compensation and the number of years the CEO has been with the firm are both positive and significant. This indicates that firms with higher ROI pay their managers better, and the CEO remains with the company for longer periods of time. The R2 for the regression is 0.031 indicating that while a number of variables explain $R O I$, the overall explanatory power of this regression is low.

Table 3: Regression Analysis

\begin{tabular}{|c|c|c|c|c|c|}
\hline Variable & Price to Earnings & ROI & ROA & Sales Growth & $\begin{array}{c}\text { Institutional } \\
\text { Ownership }\end{array}$ \\
\hline Observations & 2,877 & 3,167 & 3,180 & 3,180 & 3,180 \\
\hline Intercept & 7,421 & -636.77 & -383.76 & 3,645 & 64.37 \\
\hline Gender & $\begin{array}{c}159.57 \\
6.04 * * * \\
\end{array}$ & $\begin{array}{l}17.1854 \\
3.84 * * * \\
\end{array}$ & $\begin{array}{c}5.9107 \\
4.09 * * * \\
\end{array}$ & $\begin{array}{c}26.289 \\
2.72 * * * \\
\end{array}$ & $\begin{array}{c}-4.2596 \\
-1.81 * \\
\end{array}$ \\
\hline GICS & $\begin{array}{c}0.3289 \\
1.22\end{array}$ & $\begin{array}{c}-0.0158 \\
-0.35\end{array}$ & $\begin{array}{l}-0.0286 \\
-1.96 * *\end{array}$ & $\begin{array}{c}0.1434 \\
1.47\end{array}$ & $\begin{array}{c}-0.31953 \\
-13.83 * * *\end{array}$ \\
\hline Price to Book & $\begin{array}{c}0.08706 \\
2.03 * \\
\end{array}$ & $\begin{array}{c}0.0129 \\
1.72 * \\
\end{array}$ & $\begin{array}{l}0.00618 \\
2.54 * * * \\
\end{array}$ & $\begin{array}{c}0.0651 \\
4.02 * * * \\
\end{array}$ & $\begin{array}{c}-0.0019 \\
-0.47 \\
\end{array}$ \\
\hline Total Assets & $\begin{array}{c}-0.00005 \\
-1.11\end{array}$ & $\begin{array}{c}-0.000009 \\
-1.24\end{array}$ & $\begin{array}{l}-0.000008 \\
-3.58 * * *\end{array}$ & $\begin{array}{c}-0.000008 \\
-0.52\end{array}$ & $\begin{array}{l}-0.00002 \\
-5.34 * * *\end{array}$ \\
\hline Debt to Assets & $\begin{array}{l}-0.3654 \\
-2.43 * * \\
\end{array}$ & $\begin{array}{l}-0.0574 \\
-2.34 * * \\
\end{array}$ & $\begin{array}{l}-0.1155 \\
-16 * * * \\
\end{array}$ & $\begin{array}{c}-0.3533 \\
-7.10 * * * \\
\end{array}$ & $\begin{array}{c}0.0007 \\
0.06 \\
\end{array}$ \\
\hline Free Cash Flow & $\begin{array}{c}0.0003 \\
0.26 \\
\end{array}$ & $\begin{array}{c}0.0005 \\
2.60 * * * \\
\end{array}$ & $\begin{array}{c}0.0002 \\
2.63 * * * \\
\end{array}$ & $\begin{array}{c}-0.000001 \\
-0.00 \\
\end{array}$ & $\begin{array}{c}-0.0006 \\
-5.75 * * * \\
\end{array}$ \\
\hline ROA & $\begin{array}{c}-2.463 \\
-4.72 * * *\end{array}$ & & & $\begin{array}{c}-1.7098 \\
-14.90 * * * \\
\end{array}$ & $\begin{array}{c}0.1565 \\
5.43^{* * *} \\
\end{array}$ \\
\hline Payout & $\begin{array}{c}-0.0158 \\
-3.33 * * *\end{array}$ & $\begin{array}{c}0.00004 \\
0.07 \\
\end{array}$ & $\begin{array}{c}0.00002 \\
0.12 \\
\end{array}$ & $\begin{array}{c}0.0006 \\
0.42 \\
\end{array}$ & $\begin{array}{c}-0.00002 \\
-0.06 \\
\end{array}$ \\
\hline Sales Growth & $\begin{array}{c}1.393 \\
14.35^{* * * *}\end{array}$ & $\begin{array}{c}-0.0527 \\
-6.61 * * *\end{array}$ & $\begin{array}{c}-0.0384 \\
-14.90^{* * *}\end{array}$ & & $\begin{array}{c}0.0129 \\
2.98 * * *\end{array}$ \\
\hline Inside Ownership & $\begin{array}{c}-0.1173 \\
-0.55 \\
\end{array}$ & $\begin{array}{c}0.1005 \\
2.84 * * *\end{array}$ & $\begin{array}{c}0.0344 \\
3.02 * * * \\
\end{array}$ & $\begin{array}{c}0.3768 \\
4.97 * * * \\
\end{array}$ & $\begin{array}{c}-0.4046 \\
-23.62 * * * \\
\end{array}$ \\
\hline $\begin{array}{l}\text { Institutional } \\
\text { Ownership }\end{array}$ & $\begin{array}{c}-0.1115 \\
-0.53 \\
\end{array}$ & $\begin{array}{c}0.1629 \\
4.78 * * * \\
\end{array}$ & $\begin{array}{c}0.0590 \\
5.43 * * *\end{array}$ & $\begin{array}{c}0.2169 \\
2.98 * * *\end{array}$ & \\
\hline Founder & $\begin{array}{c}-5.616 \\
-0.39\end{array}$ & $\begin{array}{c}4.3231 \\
1.86^{*} \\
\end{array}$ & $\begin{array}{c}0.8293 \\
1.11\end{array}$ & $\begin{array}{c}47.27 \\
9.59 * * *\end{array}$ & $\begin{array}{c}-0.9709 \\
-0.80\end{array}$ \\
\hline Total Compensation & $\begin{array}{c}-0.00008 \\
-0.78 \\
\end{array}$ & $\begin{array}{c}0.00004 \\
2.16^{*} \\
\end{array}$ & $\begin{array}{l}0.00002 \\
4.20 * * *\end{array}$ & $\begin{array}{c}0.00007 \\
1.89 * \\
\end{array}$ & $\begin{array}{c}-0.000008 \\
-0.79 \\
\end{array}$ \\
\hline Years as CEO & $\begin{array}{c}-0.1328 \\
-0.25 \\
\end{array}$ & $\begin{array}{l}-0.1674 \\
-1.91 * \\
\end{array}$ & $\begin{array}{c}-0.02063 \\
-0.72 \\
\end{array}$ & \begin{tabular}{r|}
-0.5988 \\
$-3.15 * * *$ \\
\end{tabular} & $\begin{array}{c}0.2404 \\
5.21 * * * \\
\end{array}$ \\
\hline $\begin{array}{l}\text { Years with } \\
\text { Company }\end{array}$ & $\begin{array}{c}-0.5934 \\
-1.94 * \\
\end{array}$ & $\begin{array}{l}0.1255 \\
2.45^{* *} \\
\end{array}$ & $\begin{array}{l}0.05237 \\
3.18 * * * \\
\end{array}$ & $\begin{array}{c}-0.4612 \\
-4.19 * * * \\
\end{array}$ & $\begin{array}{c}-0.2612 \\
-9.86^{* * *}\end{array}$ \\
\hline Year & $\begin{array}{c}-3.764 \\
-3.11 * * * \\
\end{array}$ & $\begin{array}{c}0.3077 \\
1.50 \\
\end{array}$ & $\begin{array}{c}0.1905 \\
2.89 * * * \\
\end{array}$ & $\begin{array}{c}-1.8242 \\
-4.15 * * * \\
\end{array}$ & $\begin{array}{c}0.0184 \\
0.17 \\
\end{array}$ \\
\hline AACSB & $\begin{array}{c}13.633 \\
1.51 \\
\end{array}$ & $\begin{array}{c}0.94922 \\
0.64\end{array}$ & $\begin{array}{c}0.7793 \\
1.63 \\
\end{array}$ & $\begin{array}{c}3.520 \\
1.10 \\
\end{array}$ & $\begin{array}{c}-2.2873 \\
-2.93 * * * \\
\end{array}$ \\
\hline $\mathrm{R} 2$ & 0.1066 & 0.0337 & 0.1606 & 0.1337 & 0.2211 \\
\hline ADJ R2 & 0.1013 & 0.0288 & 0.1563 & 0.1293 & 0.2171 \\
\hline F-Statistic & $20.06 * * *$ & $6.88 * * *$ & $37.82 * * *$ & $30.50 * * *$ & $56.11 * * *$ \\
\hline
\end{tabular}

This table shows the regression results for the equation: Dependent Variable $=\alpha+\beta_{1}$ Gender $+\beta_{t}$ Control Variable ${ }_{t}+\varepsilon$. The first figure in each cell is the parameter estimate. The second figure in each cell is the $t$-statistic. ***,** and * indicate significance at the 1, 5 and 10 percent levels respectively.

The third column shows the regression results when Return on Assets, ROA, is the dependent variable. The stepwise procedure introduces eleven variables into the model. Gender has a coefficient of 5.87 and is significant at the one percent level. Like the ROI regressions above, CEO Compensation and Years with the company are positive and significant. The R2 for this regression is 0.1596 . 
The next column shows the results of regression on Sales Growth. Eleven variables are included in the final regression. Gender has a coefficient of 25.84 and is significant at the one percent level. This finding indicates that female CEO's produce higher sales growth than their male counterparts. The founder variable is positive and significant indicating that firms with a CEO who founded the firm produce more sales growth than other CEO's. The $\mathrm{R} 2$ for this regression is 0.1326 .

The final column in Table 4 shows the results of regressions on Institutional Ownership. Ten variables entered into the model with nine significant at the one percent level. Gender, was significant only at the ten percent level in this regression. The positive coefficient (4.11) for the gender variable indicates that institutions own more stock of firms with a female CEO than a male CEO. The R2 for the regression is 0.2199 , the highest R2 for any regression in this analysis.

Table 4: Stepwise Regression Analysis

\begin{tabular}{|c|c|c|c|c|c|}
\hline Variable & Price to Earnings & ROI & ROA & Sales Growth & $\begin{array}{c}\text { Institutional } \\
\text { Ownership }\end{array}$ \\
\hline Observations & 2,876 & 3,166 & 3,179 & 3,179 & 3,179 \\
\hline Intercept & $7,880.64$ & -3.7296 & -378.77231 & 3753.502 & 96.68853 \\
\hline Gender & $\begin{array}{c}163.52 \\
38.67 * * * \\
\end{array}$ & $\begin{array}{l}17.30054 \\
15.21 * * * \\
\end{array}$ & $\begin{array}{c}5.87313 \\
16.57 * * * \\
\end{array}$ & $\begin{array}{c}25.83547 \\
7.27 * * *\end{array}$ & $\begin{array}{c}4.10894 \\
3.08^{*} \\
\end{array}$ \\
\hline GICS & & & $\begin{array}{c}-0.02838 \\
3.82 *\end{array}$ & & $\begin{array}{c}-0.32346 \\
198.89 * * *\end{array}$ \\
\hline Price to Book & $\begin{array}{l}0.0858 \\
4.00 * * \\
\end{array}$ & $\begin{array}{c}0.0137 \\
3.33 * \\
\end{array}$ & & $\begin{array}{c}0.0645 \\
15.85 * * *\end{array}$ & \\
\hline Total Assets & & & $\begin{array}{c}-0.000008 \\
13.03 * * *\end{array}$ & & $\begin{array}{l}-0.00002 \\
29.08 * * *\end{array}$ \\
\hline Debt to Assets & $\begin{array}{c}-0.3781 \\
6.48 * * \\
\end{array}$ & $\begin{array}{l}-0.0588 \\
5.81 * * \\
\end{array}$ & $\begin{array}{c}-0.1153 \\
254.90 * * * \\
\end{array}$ & $\begin{array}{c}-0.3570 \\
52.41 * * * \\
\end{array}$ & \\
\hline Free Cash Flow & & $\begin{array}{l}0.0005 \\
6.37 * * \\
\end{array}$ & $\begin{array}{c}0.0002 \\
6.56^{* * *}\end{array}$ & & $\begin{array}{c}-0.0006 \\
33.89 * * *\end{array}$ \\
\hline ROA & $\begin{array}{c}-2.5170 \\
25.54 * * *\end{array}$ & & & $\begin{array}{c}-1.711 \\
224.27 * * *\end{array}$ & $\begin{array}{c}0.1511 \\
30.19 * * *\end{array}$ \\
\hline Payout & $\begin{array}{c}-0.1585 \\
11.29 * * *\end{array}$ & & & & \\
\hline Sales Growth & $\begin{array}{c}1.3760 \\
208.93 * * *\end{array}$ & $\begin{array}{c}-0.0518 \\
43.96 * * *\end{array}$ & $\begin{array}{c}-0.0379 \\
223.43 * * *\end{array}$ & & $\begin{array}{c}0.0117 \\
7.78 * * *\end{array}$ \\
\hline Inside Ownership & & $\begin{array}{c}0.0965 \\
8.01 * * *\end{array}$ & $\begin{array}{c}0.0322 \\
8.44 * * *\end{array}$ & $\begin{array}{c}0.3581 \\
23.09^{* * *}\end{array}$ & $\begin{array}{c}-0.4055 \\
561.80 * * *\end{array}$ \\
\hline $\begin{array}{l}\text { Institutional } \\
\text { Ownership }\end{array}$ & & $\begin{array}{c}0.1654 \\
25.65 * * *\end{array}$ & $\begin{array}{c}0.0578 \\
28.62 * * *\end{array}$ & $\begin{array}{c}0.1923 \\
7.61 * * *\end{array}$ & \\
\hline Founder & & & & $\begin{array}{c}47.3905 \\
94.28 * * *\end{array}$ & \\
\hline Total Compensation & & $\begin{array}{c}0.00004 \\
4.43 * * \\
\end{array}$ & $\begin{array}{c}0.00002 \\
17.72 * * * \\
\end{array}$ & $\begin{array}{c}0.00007 \\
3.38 *\end{array}$ & \\
\hline Years as CEO & & & & $\begin{array}{l}-0.5829 \\
9.46 * * *\end{array}$ & $\begin{array}{c}0.2214 \\
30.26 * * *\end{array}$ \\
\hline $\begin{array}{l}\text { Years with } \\
\text { Company }\end{array}$ & $\begin{array}{l}-0.7074 \\
7.08 * * * \\
\end{array}$ & $\begin{array}{l}0.0859 \\
3.67 * * \\
\end{array}$ & $\begin{array}{c}0.0490 \\
11.04 * * *\end{array}$ & $\begin{array}{c}-0.4951 \\
21.16 * * * \\
\end{array}$ & $\begin{array}{c}-0.2563 \\
94.87 * * * \\
\end{array}$ \\
\hline Year & $\begin{array}{c}-3.9146 \\
10.73 * * *\end{array}$ & & $\begin{array}{l}0.19130 \\
8.47 * * *\end{array}$ & $\begin{array}{l}-1.86050 \\
18.13 * * *\end{array}$ & \\
\hline AACSB & $\begin{array}{c}14.7538 \\
2.74 *\end{array}$ & & & & $\begin{array}{c}-2.027 \\
6.95 * * *\end{array}$ \\
\hline $\mathrm{R} 2$ & 0.1052 & 0.031 & 0.1596 & 0.1326 & 0.2199 \\
\hline F-Statistic & $37.44 * * *$ & $11.22 * * *$ & $46.47 * * *$ & 44.04 & $99.30 * * *$ \\
\hline
\end{tabular}

This table shows the stepwise regression results for the equation: Dependent Variable $=\alpha+\beta_{1}$ Gender $+\beta_{t}$ Control Variable $_{t}+$ $\varepsilon$. Variables with a p-value less than 0.20 were allowed to enter into the model. To remain in the model the p-value for the variable must be below 0.10. The first figure in each cell is the parameter estimate. The second figure in each cell is the F-value. ***, **and * indicate significance at the 1, 5 and 10 percent levels respectively. 


\section{CONCLUDING COMMENTS}

Newly available data allows us to examine how CEO gender impacts various firm performance measures and management variables of the largest U.S. firms. We collect data from Forbes magazine and Compustat including 6,305 firm year observations covering the time period 1997-2006. The analysis examines the relationships in three ways. First, we conduct single regressions using gender as the explanatory variable in each regression. The results show that gender has significant explanatory power for four of fourteen dependent variables considered: Return on Investment, Price to Earnings Ratio, Debt to Assets and Industry.

Next, we conduct multiple regressions that include Gender as an explanatory variable and a series of control variables. The results show that Gender significantly explains five dependent variables after accounting for the effects of the control variables. Gender significantly explains variation in Price to Earnings, Return on Investment, Return on Assets, Sales Growth and Institutional Ownership.

Finally, we use Stepwise regression to include only those explanatory variables that are significant in explaining dependent variable variance. The results include between nine and eleven variables in the regression models. In each case, Gender is a significant explanatory variable. The R2 statistics for the regressions range in value from 0.031 to 0.2199 .

The results presented here clearly indicate that female CEO's manage their firms differently and are perceived differently by financial markets. In general, female CEO's produce higher sales growth, more institutional ownership, provide higher returns in the form of $R O I$ and $R O A$ and are valued higher in the market than firms managed by male CEO's. The results presented here are exploratory in nature. The number of female CEO's is relatively low with only 77 firm year observations out of 6,305 involving a female CEO. In the future, as more females become CEO's of large public firms, additional analysis will become possible.

\section{AUTHOR INFORMATION}

Terrance Jalbert is Professor of Finance at the University of Hawaii at Hilo. His research appears in Journals that include, International Journal of Finance, Financial Services Review, Journal of Index Investing, Journal of Applied Business Research, International Journal of Business and Finance Research and Journal of Accounting Education. He can be reached at University of Hawaii at Hilo, College of Business and Economics, 200 West Kawili St., Hilo, HI 96720. E-mail: jalbert@hawaii.edu (Corresponding author)

Mercedes Jalbert is Managing Editor for the Institute for Business and Finance Research. Her research appears in journals such as Accounting and Taxation, Tax Notes, Journal of Emerging Markets, International Journal of Management and Marketing Research and Financial Services Review. She can be reached at P.O. Box 4908, Hilo, HI 96720 E-mail: $\underline{\text { admin @theIBFR.com }}$

Kim Furumo is Associate Professor of Management Information Systems. Her research appears in journals that include Communications of the ACM, the Journal of Computer Information Systems, the Interdisciplinary Journal of Information, Knowledge, and Management, the Journal of Information Technology Cases and Applications, the Journal of Information, Information Technology, and Organizations, and the International Journal of Electronic Marketing and Retailing She can be reached at University of Hawaii at Hilo, College of Business and Economics, 200 West Kawili St., Hilo, HI 96720. E-mail: furumo@ hawaii.edu

\section{REFERENCES}

1. Bhattacharyya, N., Amin M. and C. K.J. Moril (2008a) "Dividend Payout and Executive Compensation: Theory and Canadian Evidence," Managerial Finance, vol. 34(8), p. 585-601

2. Bhattacharyya, N., A. Mawani and C. K.J. Moril (2008b) "Dividend Payout and Executive Compensation: Theory and Evidence," Accounting and Finance, vol. 48(4, December), p. 521-541

3. Barker, V.L. and G.C. Mueller (2002) "CEO Characteristics and Firm R\&D Spending," Management Science, vol. 48(6, June) p. 782-801 
4. DeAngelo, H. and R. Masulis. (1980) "Optimal Capital Structure Under Corporate and Personal Taxation," The Journal of Financial Economics. March, 3-30

5. Easterbrook, F. (1984) Two Agency-Cost Explanations of Dividends. American Economic Review. v. 74 (September), 650-59.

6. $\quad$ Fahlenbrach, R. (2009) "Founder CEOs and Stock Market Performance," Journal of Financial and Quantitative Analysis, vol. 44, p. 439-466

7. Forbes Magazine Forbes Compensation 800 List. Forbes Magazine. May Issues. 1997-2006.

8. Gabaix, X and A. Landier (2008) "Why has CEO Pay Increased so Much," The Quarterly Journal of Economics, vol. 123(1), p. 49-100

9. Gottesman, A. A. and M. R. Morey (2006) "Does a Better Education Make For Better Managers? An Empirical Examination of CEO Educational Quality and Firm Performance," (April 21). Available at SSRN: http://ssrn.com/abstract=564443

10. Hermalin, B. (2005) "Trends in Corporate Governance," Journal of Finance vol. 60, p. 2351-2384.

11. Jalbert, T. 2002. Pass-Through Taxation and the Value of the Firm. The American Business Review. V. 20(2) 47-54

12. Jalbert, T., M. Jalbert and K. Furumo (2011) "Does AACSB Accreditation Matter?, Evidence from Large Firm CEO's, Journal of Applied Business Research, vol. 27(3), p. 93-106

13. Jalbert, T., K. Furumo and Mercedes Jalbert (2011) "Does Educational Background Affect CEO Compensation and Firm Performance?" Journal of Applied Business Research, Vol. 27(1, January/February) p. 15-40

14. Jalbert, T. and M. Jalbert (2005) "Founders versus non-founders: An Empirical Analysis of CEO Educational Background" Review of Business Research Vol. V(1), p. 87-100

15. Jalbert, T., M. Jalbert and G. Perrina (2004) "Does Degree Matter? An Empirical Analysis of CEO Educational Paths," Journal of College Teaching and Learning Vol. 5(1) May p. 65-73

16. Jalbert, T., R. Rao, and M. Jalbert (2002) "Does School Matter? An Empirical Analysis of CEO Education, Compensation and Firm Performance," International Business and Economics Research Journal, Vol. 1(1) Winter, p. 83-98

17. Miller, M. 1977. Debt and Taxes. Journal of Finance. May, 261-75

18. Miller, M. and F. Modigliani. (1961) "Dividend Policy, Growth and the Valuation of Shares," Journal of Business. v. 34(October) 411-33

19. Modigliani, F., and M. Miller (1958) "The Cost of Capital, Corporation Finance, and the Theory of Investment. American Economic Review. June, 261-297

20. Modigliani, F., and M. Miller (1963) “Corporate Income Taxes and the Cost of Capital," American Economic Review. June, 433-43

21. Murphy, K. (2003) Stock-Based Pay in New Economy Firms. Journal of Accounting and Economics, v. $34,129-47$

22. Murphy, K. and B. Hall (2002) Stock Options for Undiversified Executives. Journal of Accounting and Economics. v. 33(1, February), 3-42

23. Palia, D. and A. Ravid (2002) "The Role of Founders in Large Companies: Entrenchment or Valuable Human Capital?" Working Paper.

24. Palia, D. (2000) “The Impact of Regulation on CEO Labor Markets," RAND Journal of Economics, vol. 31(1, Spring), p. 165-179

25. Wiersema, M. F., and K. A. Bantel (1992) "Top Management Team Demography and Corporate Strategic Change." Academy of Management Journal 35: 91-12. 


\section{NOTES}

